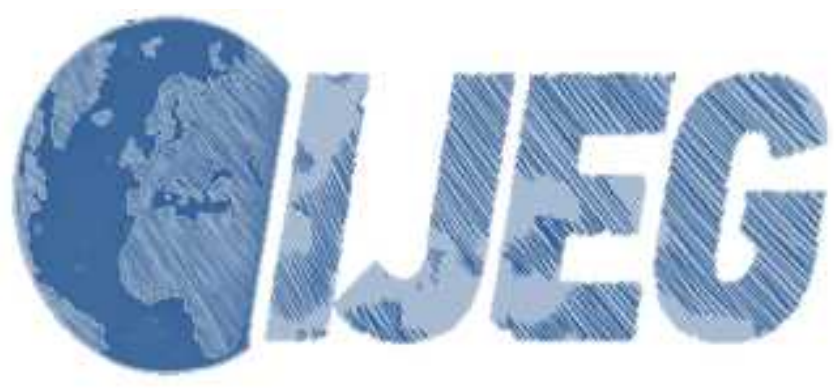

International Journal of Engineering and Geosciences (IJEG), Vol; 2; , Issue; 03, pp. 84-90, October, 2017, ISSN 2548-0960, Turkey, DOI: $10.26833 /$ ijeg.317314

\title{
DETERMINATION OF TEMPORARY SHELTER AREAS IN NATURAL DISASTERS BY GIS: A CASE STUDY, GÖLCÜK/TURKEY
}

\author{
Şentürk, E., ${ }^{1 *}$ and Erener, A., ${ }^{1}$ \\ ${ }^{1}$ Kocaeli University, Engineering Faculty, Department of Geomatic Engineering, Kocaeli, Turkey \\ (erman.senturk/arzu.erener@kocaeli.edu.tr);
}

ORCID 0000-0002-0833-7113; ORCID 0000-0002-9168-4254

*Corresponding Author, Received: 30/05/2017, Accepted: 10/08/2017

\begin{abstract}
Disaster is a natural or human-induced event that adversely affects the individual or the society. The magnitude of a disaster is measured by directly proportional to the damage it causes. In order to bring disaster and damage to a minimum level, it is quite important to plan and implement the evacuation and to place the victims in a safer region. Therefore, in this study the most suitable temporary shelter site selection will be investigated by the multi-criteria decision analysis method based on GIS for Kocaeli Gölcük district. For this purpose, 15 criteria were determined by considering literature search, the mutual interviews with the disaster experts and priorities of the Gölcuik district. Analytical Hierarchy Process (AHP) was used to determine the criteria weights. Analyses were made using ArcGIS, QGIS, and ERDAS software. All raster maps were classified at the same scale, the classification was completed by giving the highest score for the most suitable conditions and the lowest score for the unsuitable conditions. Classified raster maps were used in the overlay analysis on GIS and suitability map of temporary shelter areas was obtained for Gölcük district. As a result, $243.900 \mathrm{~m}^{2}$ of temporary shelter region was selected by a manual process from the most and very suitable areas within the boundary of the Gölcük.
\end{abstract}

Keywords: GIS, Multi-Criteria Decision Analysis, Natural Disaster, Temporary Shelter 


\section{INTRODUCTION}

Being prepared for disasters will ensure that there is an opportunity to prevent possible losses and have an idea of how to act in the event of a disaster. Disaster management is defined as the planning, directing, supporting, coordinating and effective implementation of activities to be carried out at the stages of damage mitigation, preparation, intervention, and recovery in order to prevent disasters and reduce their damages (Poser and Dransch, 2010). The development of a rapid and effective disaster management system is very important in order to prevent the negative consequences of disasters. For this purpose, it is necessary to determine the risks that may lead to a disaster and to take precautions to prevent or minimize these risks at the most appropriate level. The role of a temporary shelter is to provide to those needing to seek immediate relief after a natural disaster. In the event of a disaster quickly directing the people from their living region to shelter areas provides the reduction of the possible losses. Additionally, it prevents the disappearances, cause quick intervention of injured people by medical teams and helps the professional teams to complete their work in a more comfortable way. In a temporary shelter area, there should be no risk of direct disaster impact and basic facilities such as electricity, water, sewerage and communication should be available for people's daily lives. In addition, the proximity of these areas to markets, warehouses, and health centers needs to be assessed in advance for the purpose of providing food, drinking water, and other supplies. Geographical features such as closeness to water resources, proximity to transportation networks, morphological characteristics, climatic characteristics, hydrographic characteristics, soil characteristics, proximity to vegetation cover and environment are important in determining these sites (Özdemir, 2002).

There are various studies related to shelter area selection and logistics in disaster management. Yi and Özdamar (2004) proposed a dynamic and fuzzy coordination logistic model to manage disaster reaction activities and they applied their study on Istanbul earthquake data. Zhu et al. (2010) worked on emergency source repositories and capacities and proposed a model to minimize total cost. Mete and Zabinsky (2010) included a detailed literature for the problem of location selection and distribution in the medical supplies procurement process in disaster management and proposed a stochastic programming model for this problematic structure. Lixin et al. (2012) reviewed the disaster management system in China and made suggestions to improve the quality of the system by analyzing the distresses. Soltani et al. (2015) applied the Delphi method for temporary shelter areas after major earthquakes in three stages and determined the 21 criteria collected under 4 main headings which can be chosen as the criteria for the best temporary gathering area location. Xu et al., (2016) was introduced seven principles (i.e., safety, control of land use, nearest evacuation point, economic constraints, appropriate travel distance/time, maximum coverage and population capacity) to guide the planning of earthquake evacuation shelters using an iterative solution method to the multicriteria model based on GIS.
In this study, the problem of determining the most suitable temporary shelter areas for disaster management was discussed. 15 criteria were selected and Analytical Hierarchy Process (AHP) was used to determine the criteria weights. The Multi-Criteria Decision Analysis (MCDA), which is used extensively in location selection problems (Doerner et al., 2009; Nobre et al., 2009; Reubens et al., 2011) and others (Kavzoglu et al., 2014; Shokati et al., 2016), was used together with GIS to decide suitable temporary shelter areas in Gölcük.

\section{STUDY AREA AND DATA}

In the study, the most suitable temporary shelter areas were determined in the Kocaeli/Gölcük by the MCDA. Gölcuik is located on the southern coast of the Gulf of Izmit and towards the east of the Gulf, with a width of up to $2 \mathrm{~km}$. The town area has approximately $228 \mathrm{~km}^{2}$. Figure 1 shows the study area.

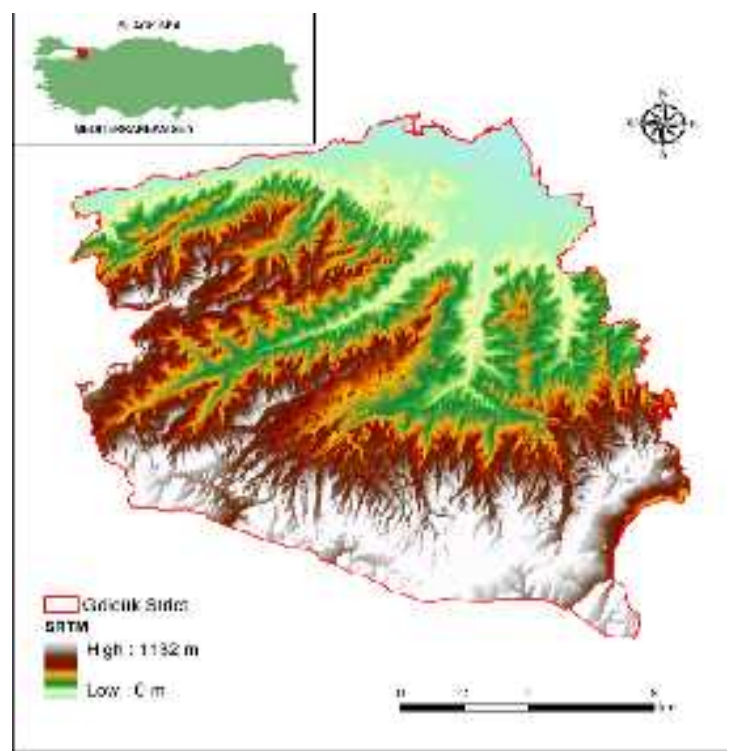

Figure.1 The study area

Table 1 shows the type, scale and product year of the data used for the criteria. The criteria details were generally obtained from the CAD data and digital maps. The land slope was produced from ASTER Global DEM data. Especially, the CAD data is constantly updated by the Gölcük Municipality.

Table 1 Type, scale and year of the data

\begin{tabular}{|l|l|l|l|} 
Map & Type & Scale & Year \\
\hline \multirow{4}{*}{ Plan } & CAD & & \\
& $\begin{array}{l}\text { Fuel stations and } \\
\text { flammable material } \\
\text { storage }\end{array}$ & & \\
& $\begin{array}{l}\text { Road networks } \\
\text { Security centers }\end{array}$ & \multirow{2}{*}{$1 / 1000$} & \multirow{2}{*}{2016} \\
& $\begin{array}{l}\text { Existing buildings } \\
\text { Electricity } \\
\text { transmission line }\end{array}$ & & \\
& & \\
\end{tabular}




\begin{tabular}{|c|c|c|c|}
\hline & Medical centers & & \\
\hline & Polluting industries & & \\
\hline & Cultural heritage & & \\
\hline & Water supply & & \\
\hline & Electrical supply & & \\
\hline $\begin{array}{l}\text { Land } \\
\text { slope }\end{array}$ & $\begin{array}{l}\text { ASTER Global } \\
\text { DEM }\end{array}$ & $30 \mathrm{~m}$ & 2015 \\
\hline Fault & Vector map & $1 / 5000$ & 2010 \\
\hline Landslide & Digital Map & $1 / 25000$ & 2002 \\
\hline Geology & Digital Map & $1 / 25000$ & 2000 \\
\hline Flood & Digital Map & $1 / 5000$ & 2010 \\
\hline
\end{tabular}

\section{METHOD AND ANALYSIS}

It is important to consider alternatives for decision makers in multi-criteria decision analysis, to rank alternatives according to their importance, and to choose the one with the highest priority among alternatives for decision making (Jahanshahloo et al., 2006). Figure 2 shows the work flow steps of the analysis for the study. In this study initially, 15 criteria were determined by considering literature search, the mutual interviews with the disaster experts and priorities of the Gölcük town. The spatial and attribute data for the criterions were obtained from digital maps and satellite images. The accuracy and reliability of the data were tested during the selection data. It has been taken into consideration that spatial data were generated in the same coordinate system and close accuracy. In addition, the attribute data has been confirmed by metadata's or consultation with organization authorities.

Vector maps of each criterion were transformed to raster format with $10 \times 10 \mathrm{~m}$ cell size by various spatial analyses (distance analysis, density analysis, slope analysis, view analysis, buffer analysis, etc.). Analyses were made with the aid of ArcGIS, QGIS, and ERDAS. The raster format maps obtained as a result of the spatial analysis were classified according to pre-determined conditions. The classification process was based on a range of $0-5$ points. All raster maps were classified at the same scale, the classification was completed by giving the highest score (5) for the most suitable conditions and the lowest score (0) for the unsuitable conditions.
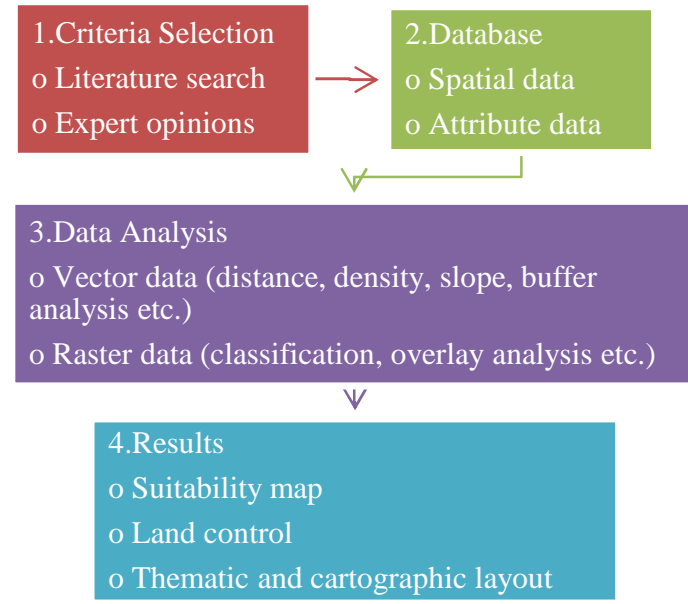

Figure.2 The workflow of the analysis

Determination of the weights of the criteria is another important part of the MCDA. At this stage, it is necessary to take advantage of previous experiences and expert opinions. However, since expert opinions often produce subjective results, it is important that the decisions made are confirmed by multiple decisionmaking analyses, such as the Analytic Hierarchy Process (AHP). The AHP was first proposed by Myers and Alpert in 1968 and developed in 1977 as a model by Saaty to solve decision-making problems (Myers and Alpert, 1968; Saaty, 1977). AHP is a method of decision-making and estimation that gives percentage distributions of decision points in terms of factors affecting the decision, which are used when the decision hierarchy can be defined. The AHP holdouts a benchmark on a decision hierarchy, using a pre-defined comparison scale, factors that influence decision making and, the significance of decision points in terms of these factors. Thus, the differences in importance are transformed into percentages on the decision points. Criterion weights were determined using the AHP method from surveys conducted by experts on disaster.

Table 2 shows the criteria's, analysis methods, classification methods, classification intervals, class points and criterion weights. In addition, Figure 3 shows the 15 classified raster maps used in the overlay analysis.

Table 2 Criteria, analysis, classification method, classification interval, class points and criterion weights

\begin{tabular}{cccccc}
\hline Criteria & Analysis Method & $\begin{array}{c}\text { Classification } \\
\text { Method }\end{array}$ & Classification Interval* & $\begin{array}{c}\text { Class } \\
\text { Point }\end{array}$ & $\begin{array}{c}\text { Criterion } \\
\text { Weight }\end{array}$ \\
\hline $\begin{array}{c}\text { Suitable distance from } \\
\text { fuel stations and } \\
\text { flammable material } \\
\text { storage areas }\end{array}$ & $\begin{array}{c}\text { Distance (Straight } \\
\text { Line) }\end{array}$ & Manuel & $0-30$ & 0 & $0.13(\% 13)$ \\
& & & $30-14883.24$ & 5 & \\
Proximity to road & Distance (Straight & Natural breaks & $0-513.89$ & 5 & \\
networks & Line) & & $8396.46-8279.04$ & 3 & $0.05(\% 5)$ \\
& & & $12161.61-14938.76$ & 1 & \\
Proximity to security & Distance (Straight & Natural breaks & $0-836.28$ & 5 & \\
centers & Line) & & $8119.37-7402.46$ & 3 & $0.03(\% 3)$ \\
& & & $7402.46-10685.55$ & 2 & \\
\hline
\end{tabular}


International Journal of Engineering and Geosciences (IJEG),

Vol; 2; , Issue; 03, pp. 84-90, October, 2017,

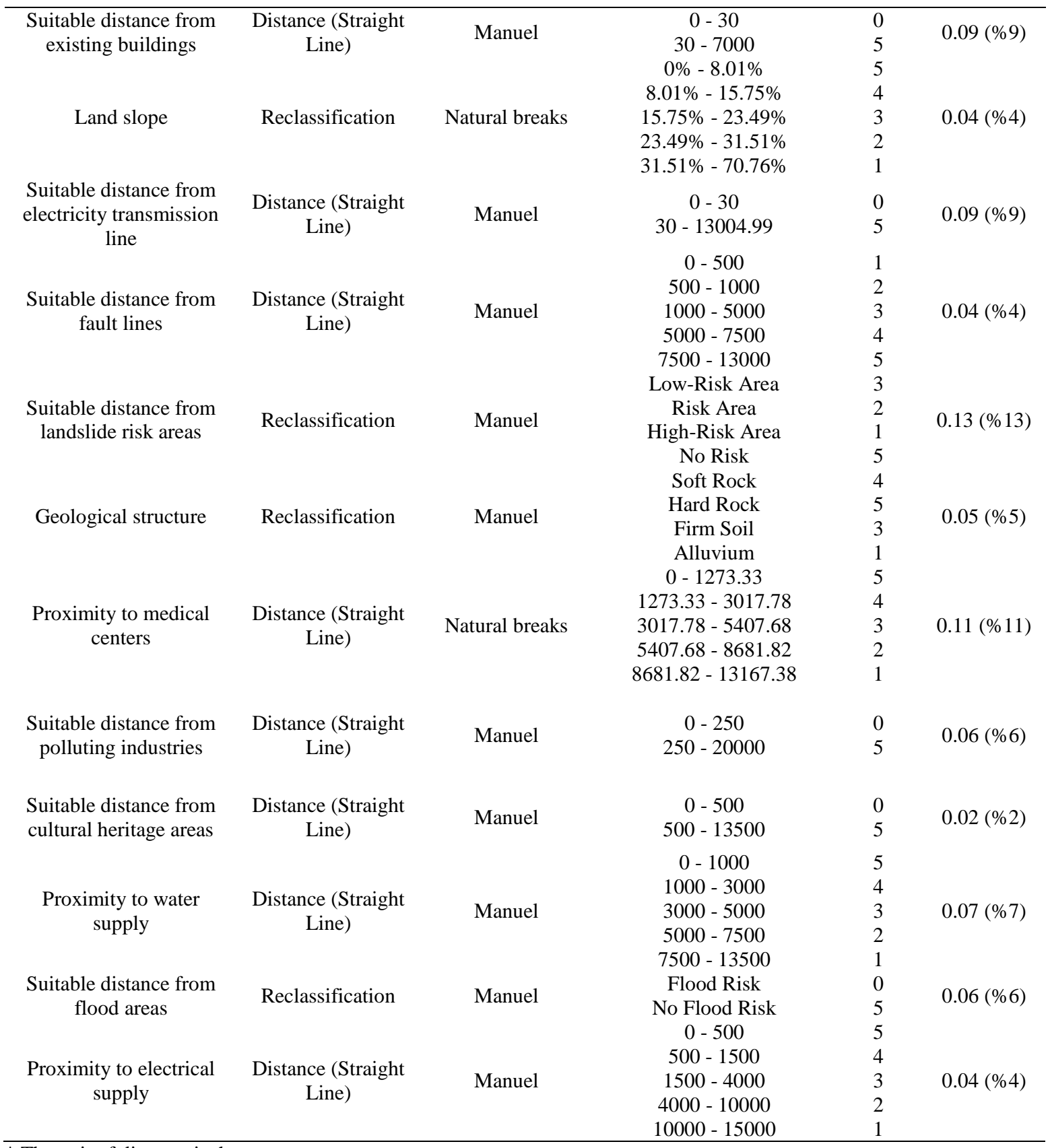

* The unit of distance is the meter. 


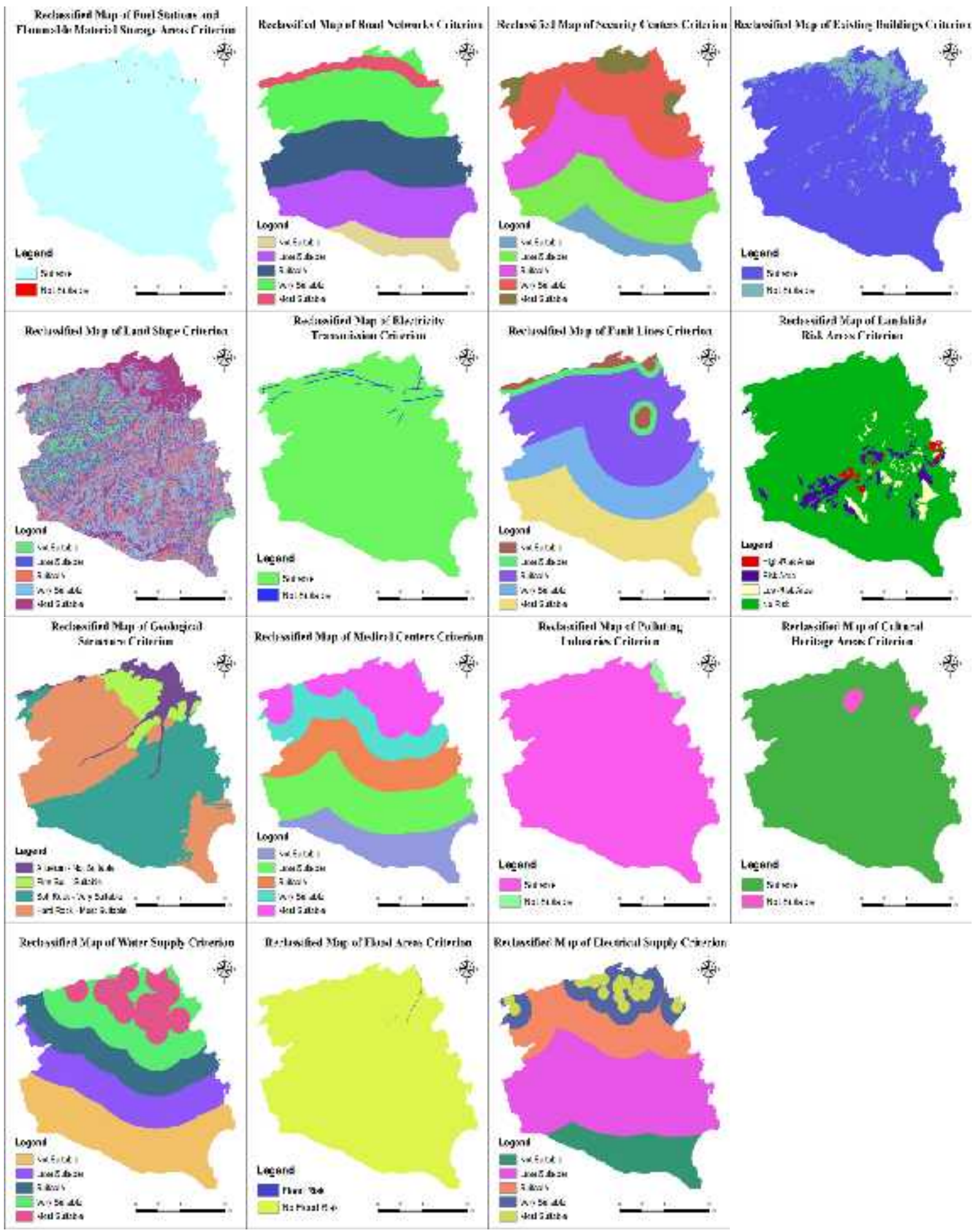

Figure.3 Classified raster maps of criteria

Classified and weighted maps were combined with the help of overlay analysis to obtain a suitable areas result map. Weighted sum method was applied in overlay analysis. In the weighted sum based overlay analysis, the total scores of the cells for the result map were determined by multiplying the scores given to each cell by the weight values in the maps classified in the same cell dimensions. In most cases, the result map was categorized so that each class was considered to be not suitable, less suitable, suitable, very suitable, and most suitable.

In Figure 4, the suitability map of temporary shelter areas in Gölcük was showed. As a result of the overlay analysis, not suitable, less suitable, suitable, very suitable and most suitable areas were classified and colored as red, orange, light green, light blue and blue, respectively. The result map coordinate system is WGS84 UTM Zone 35N. Figure 3 depict that the most suitable areas are located in the north and northwest of 
the Gölcük town where the population is more intense. In Table 3, the size of classified regions was showed. According to the Sphere Project, which is based on the Humanitarian Charter Convention, international humanitarian principles and conditions, the human rights convention, the Refugee Law, the International Committee of the Red Cross (ICRC) and NGO law, the per capita area including infrastructure services are defined as $45 \mathrm{~m}^{2}$. By 2016, the population of the Gölcük is 156,901 with reference to Turkish Statistical Institute. Accordingly, temporary shelter area of approximately $7.06 \mathrm{~km}^{2}$ is needed in Gölcük. This demand can be supplied with the most suitable and very suitable areas.

Table 3 Size of classified regions

\begin{tabular}{lll}
\hline Class & Area size $\left(\mathrm{km}^{2}\right)$ & Area size $(\%)$ \\
\hline Not suitable & 17.79 & 7.9 \\
Less suitable & 63.28 & 28.1 \\
Suitable & 104.28 & 46.4 \\
Very suitable & 36.46 & 16.2 \\
Most suitable & 3.17 & 1.4 \\
\hline Total & 224.98 & 100 \\
\hline
\end{tabular}

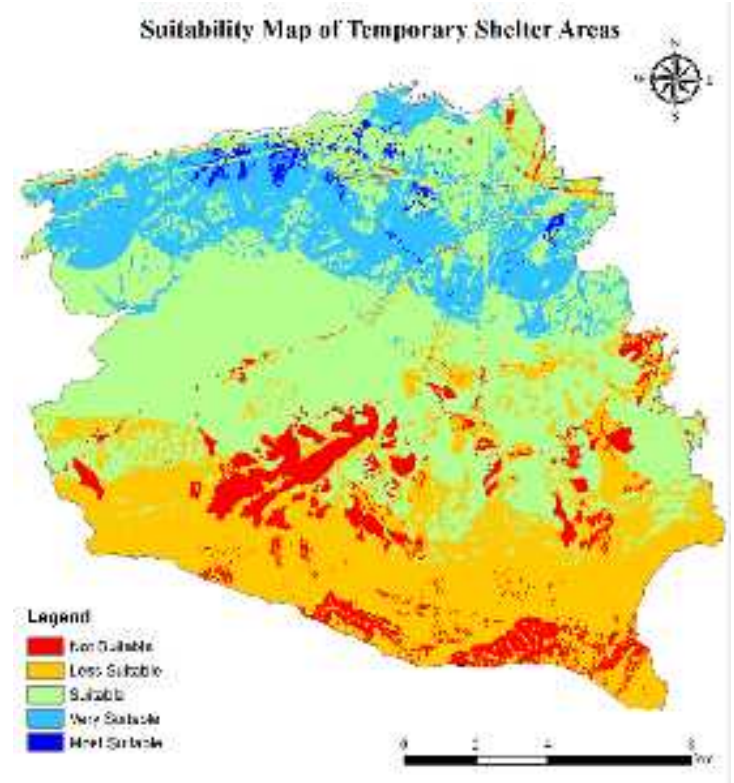

Figure. 4 The suitability map of temporary shelter areas

The selected temporary shelter areas in Gölcük town are shown in Figure 5. $243.900 \mathrm{~m}^{2}$ of temporary shelter is selected by a manual process from the most and very suitable areas within the boundary of the Gölcük.

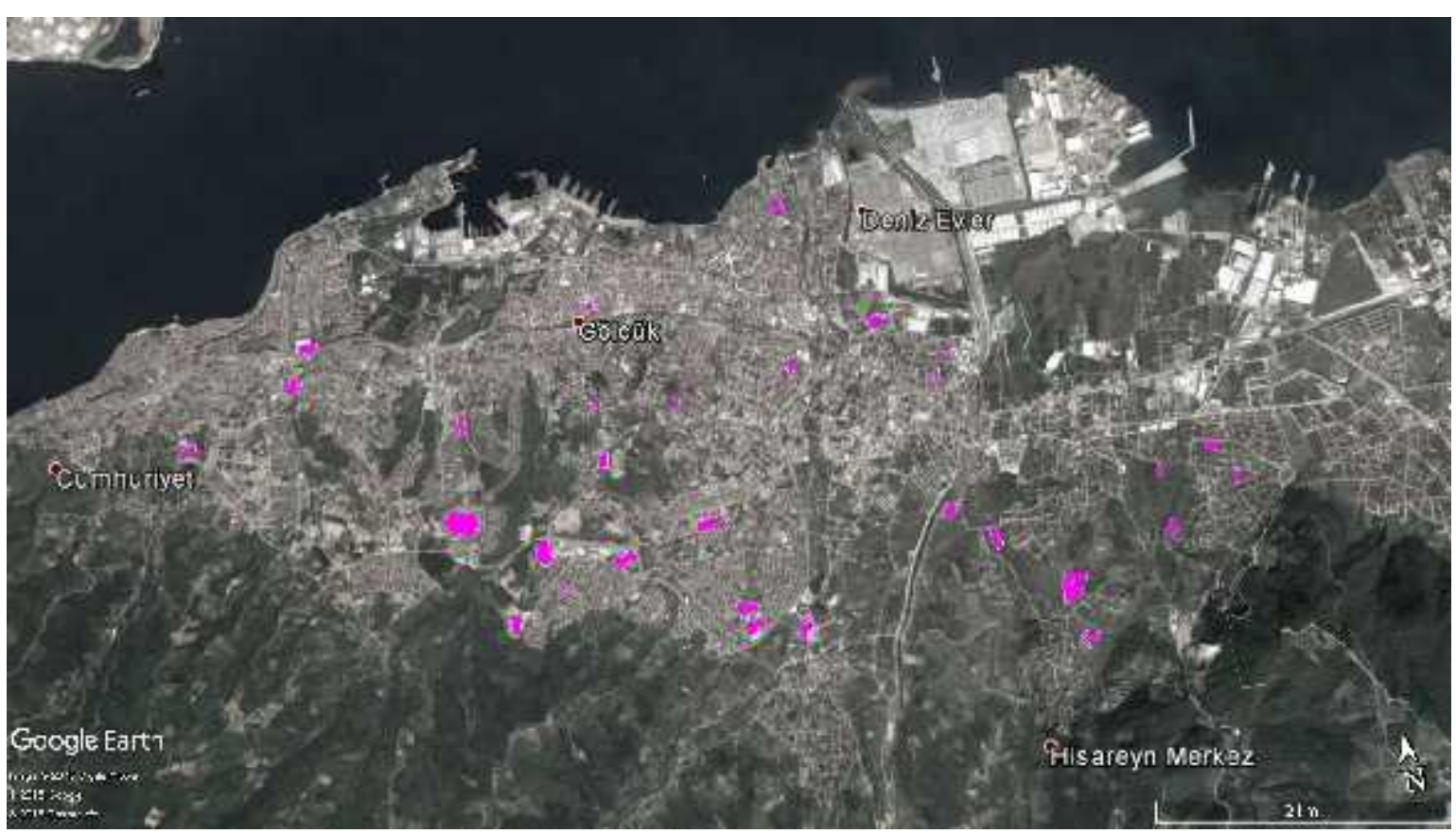

Figure. 5 Selected temporary shelter areas in Gölcük town

\section{CONCLUSION}

This study has contributed to the Gölcük district be more prepared against disasters that might occur in the future. This study has critical importance for quickly routing the victims to the temporary shelter areas, minimizing the potential losses, completing the professional teamwork in a more comfortable way, avoiding disappearances and intervention of the health care teams to the injured people in a fastest way. For this purpose, suitability map of shelter areas was obtained by GIS technology. A multi-criteria decision process was applied and the criteria weights were determined by the analytical hierarchical process to obtain more accuracy results. According to suitability map, the most suitable areas are located in the north and northwest of the Gölcuik town. Especially in the southern, where people are infrequently populated, there are not suitable places for temporary 
shelter areas. Specified regions indicate the probability of alternatives being the best decision.

\section{ACKNOWLEDGEMENTS}

This study was supported by Academic Research Project Gölcük Vizyon 2023. The authors would like to thank to Kocaeli University and Golcuk Municipality for the support of the study.

\section{REFERENCES}

Doerner, K.F., Gutjahr, W.J., Nolz, P.C., 2009. Multicriteria location planning for public facilities in tsunamiprone coastal areas. Or Spectrum, 31(3), 651-678.

Erener, A., Düzgün, S., Yalciner, A.C., 2012. Evaluating land use/cover change with temporal satellite data and information systems. Procedia Technology, 1, 385-389.

Jahanshahloo, G.R., Lotfi, F.H., Izadikhah, M., 2006. Extension of the TOPSIS method for decision-making problems with fuzzy data. Applied Mathematics and Computation, 181(2), 1544-1551.

Kavzoglu, T., Sahin, E.K., Colkesen, I., 2014. Landslide susceptibility mapping using GIS-based multi-criteria decision analysis, support vector machines, and logistic regression, Landslides, 11(3), 425-439.

Lixin, Y., Lingling, G., Dong, Z., Junxue, Z., Zhanwu, G., 2012. An analysis on disasters management system in China. Natural hazards, 60(2), 295-309.

Mete, H.O., Zabinsky, Z.B., 2010. Stochastic optimization of medical supply location and distribution in disaster management. International Journal of Production Economics, 126(1), 76-84.

Myers, J.H., Alpert, M.I., 1968. Determinant buying attitudes: meaning and measurement. The Journal of Marketing, 13-20.

Nobre, A., Pacheco, M., Jorge, R., Lopes, M.F.P., Gato, L.M.C., 2009. Geo-spatial multi-criteria analysis for wave energy conversion system deployment. Renewable energy, 34(1), 97-111.

Özdemir, H., 2002. Afetlere Hazırlık Aşamasında Geçici skân Alanlarının Belirlenmesi. Doğu Coğrafya Dergisi, $12,237-254$
Poser, K., Dransch, D., 2010. Volunteered geographic information for disaster management with application to rapid flood damage estimation. Geomatica, 64(1), 89-98.

Reubens, B., Moeremans, C., Poesen, J., Nyssen, J., Tewoldeberhan, S., Franzel, S., Deckers, J., Orwa C., Muys, B., 2011. Tree species selection for land rehabilitation in Ethiopia: from fragmented knowledge to an integrated multi-criteria decision approach. Agroforestry Systems, 82(3), 303-330.

Saaty, T.L., 1977. A scaling method for priorities in hierarchical structures. Journal of mathematical psychology, 15(3), 234-281.

Shokati, B., Asgharipour, M. R., Ghanbari, A., \& Feizizadeh, B., 2016. Suitability assessment of Saffron cultivation using GIS based multi-criteria decision analysis approach; study area: East-Azerbaijan province. Desert, 21(2), 115-131.

Soltani, A., Ardalan, A., Boloorani, A.D., Haghdoost, A., Hosseinzadeh-Attar, M.J., 2015. Criteria for Site Selection of Temporary Shelters after Earthquakes: a Delphi Panel, PLOS Currents Disasters, 7, 1-13.

The Sphere Project. 2000. Oxfam GB. Oxford, U.K.

Xu, J., Yin, X., Chen, D., An, J., Nie, G., 2016. Multicriteria location model of earthquake evacuation shelters to aid in urban planning. International Journal of Disaster Risk Reduction, 20, 51-62.

Yi, W., Ozdamar, L., 2004. Fuzzy modeling for coordinating logistics in emergencies. International Scientific Journal of Methods and Models of Complexity-Special Issue on Societal Problems in Turkey, 7(1), 20.

Zhu, J., Liu, D., Huang, J., Han, J. (2010, August). Determining storage locations and capacities for emergency response. In The Ninth International Symposium on Operations Research and Its Applications (ISORA'10), pp. 262-269.

Copyright (C) International Journal of Engineering and Geosciences (IJEG). All rights reserved, including the making of copies unless permission is obtained from the copyright proprietors. 